\title{
Impact of ecotourism on the fish fauna of Bonito region (Mato Grosso do Sul State, Brazil): ecological, behavioural and physiological measures
}

\author{
Ana Carolina Lima ${ }^{1,6}$, Jorge Assis ${ }^{2}$, Diogo Sayanda ${ }^{3}$, José Sabino ${ }^{4}$ and Rui F. Oliveira ${ }^{1,5}$
}

Bonito, in Mato Grosso do Sul State, is an important destination for ecotourism in Brazil and the main challenge of sustainable ecotourism here has been to accommodate and adjust the increase of tourism without compromising the ecological integrity of the local ecosystems. In this study we aimed to assess the environmental impact of ecotourism on the fish fauna of Sucuri River in Bonito by integrating ecological, behaviour and physiological criteria and using the fish species Crenicichla lepidota and Moenkhausia bonita as indicators. Two distinct sites were defined to collect data: (1) affected daily by ecotourism (Tourism) and (2) undisturbed (No Tourism). The "stationary point count" method was performed to assess variations in ecological parameters and "ad libitum" and focal animal methods were used to collect behaviour data. The cortisol response of M. bonita to a stress protocol was measured from holding-water. Results showed a significantly increase in species richness, density and diversity at the Tourism site. Nevertheless, behaviour patterns indicated a higher stress at the Tourism site for both species as well higher cortisol levels for M. bonita. In opposition to the ecological measures, the behaviour and physiological ones may be interpreted as an early sign of negative impact caused by ecotourism, prior to changes at community level.

Bonito, no estado de Mato Grosso do Sul, é atualmente um importante destino de ecoturismo no Brasil e o seu principal desafio tem sido o de acomodar e ajustar de forma sustentável a crescente procura de turistas sem comprometer a sua integridade ecológica. O objetivo deste estudo consistiu em avaliar o impacto do ecoturismo na ictiofauna do rio Sucuri localizado em Bonito, através da utilização integrada de critérios ecológicos, comportamentais e fisiológicos e utilizando as espécies de peixes Crenicichla lepidota e Moenkhausia bonita como indicadores. Para tal foram determinadas duas áreas distintas de amostragens no rio: (1) local onde ocorrem visitas turísticas diárias (Tourism) e (2) local sem qualquer tipo de impacto humano (No Tourism). O método de censos visuais por pontos fixos foi utilizado para determinar variações nos parâmetros ecológicos e os métodos "ad libitum" e animal focal foram utilizados para coletar dados comportamentais para as duas espécies em estudo. A resposta fisiológica à presença de turistas foi testada em $M$. bonita através da determinação de cortisol na água por um método não-invasivo de captura, transporte e confinamento. Os resultados obtidos indicam que no local exposto ao turismo há um aumento significativo da riqueza específica, densidade e diversidade de espécies. No entanto, a nível comportamental $C$. lepidota apresenta mudanças significativas de comportamento alimentar, agonístico, de fuga e guarda do ninho entre os dois locais. Moenkhausia bonita apresenta mudanças significativas não só a nível do seu comportamento alimentar e de fuga, mas também apresenta níveis de cortisol significativamente superiores no local com turismo. Contrariamente aos dados ecológicos, os resultados comportamentais e fisiológicos poderão ser interpretados numa primeira análise como impactos negativos do ecoturismo que surgem em antecipação a mudanças significativas na estrutura e composição das comunidades.

Key words: Behaviour, Cortisol, Crenicichla lepidota, Moenkhausia bonita, Stress response.

\footnotetext{
${ }^{1}$ Unidade de Investigação em Eco-Etologia, Instituto Superior de Psicologia Aplicada. Rua Jardim do Tabaco 34, 1149-041 Lisboa, Portugal. ruiol@ispa.pt

${ }^{2}$ Centro de Ciências do Mar, Universidade do Algarve, 8005-139 Faro, Portugal.

${ }^{3}$ Departamento de Estatística e Investigação Operacional, Faculdade de Ciências da Universidade de Lisboa, Bloco C 6, Piso 4 - Campo Grande, 1749-016 Lisboa, Portugal.

${ }^{4}$ Universidade Anhanguera-UNIDERP. Rua Ceará, 333, Bairro Miguel Couto, Caixa Postal 2153, 79003-010 Campo Grande, MS, Brazil. ${ }^{5}$ Champalimaud Neuroscience Programme, Instituto Gulbenkian de Ciência. Rua da Quinta Grande 6, 2780-156 Oeiras, Portugal.

${ }^{6}$ Universidade de Aveiro, Campus Universitário de Santiago, 3810-193 Aveiro, Portugal. carolina.alveslima@gmail.com
} 


\section{Introduction}

Ecotourism is a sustainable form of natural resourcebased tourism that focuses primarily on experiencing and learning about nature, and which is ethically managed to be low-impact, non-consumptive, and locally oriented (Fennell, 1999). Typically it is practiced in natural areas, and should contribute to their conservation or preservation. Nevertheless, the increase of this activity may have a negative interference in the natural balance of ecosystems, affecting diversity, ecology and behaviour of its species (Buckley, 2001; Cole, 1993; Liddle, 1997; Newsome et al., 2002; Smyth et al., 2005; Willink et al., 2000). Hence, whether the ecotourism in protected areas really contributes for the protection of habitats/species has been a matter of debate (Duffus \& Dearden, 1990; King \& Stewart, 1996). In order to find balance between ecotourism and the ecosystems' integrity, defined by Karr \& Dudley (1981) as "the capability of supporting and maintaining a balanced, integrated, adaptive, community of organisms having species composition, diversity, and functional organization comparable to that of natural habitats of the region", further studies on the effect of tourism related stressors are required and the evaluation of their impact in wild life needs to be assessed.

The region of Bonito is an important destination for ecotourism in Brazil, with a strong tendency to increase its visitors (Sabino \& Andrade, 2003). The lack of knowledge about species biodiversity and the real impact of ecotourism make it a priority site for ecological studies. The main challenge here is to accommodate and adjust this increase of visitors without compromising ecosystems' integrity (Cifuentes, 1992; Mitraud, 2001; Sabino \& Andrade, 2002; Takahashi, 1997).

Initial symptoms of negative impacts on freshwater ecosystems may be difficult to perceive, especially when there is little or no data on baseline conditions to compare with (Buckley, 1999). Comprehensive baseline surveys are rarely conducted at the outset because time, budgets and technical resources are limited and the needs are not perceived. Often, it is only when severe impacts are manifested that questions are asked and management actions are deemed necessary (Rome, 1999).

The most common way of assessing environmental impacts in natural habitats is by ecological parameters such as species richness, diversity, evenness and density (e.g., Garay \& Dias, 2001; Mitraud, 2001; Sabino \& Andrade, 2002). Nevertheless, other parameters like behaviour (Godfrey \& Barreto, 1995; Shumway, 1999) and physiology- cortisol levels in reference species (Mullner et al., 2004; Wysocki et al., 2006) - can provide complementary information and have been increasingly used. Behavioural responses are an animal's first line of defence against adverse environmental change, often being triggered by the same stimuli that initiate the primary stress response (FSBI, 2002). Cortisol is the main glucocorticoid produced by the teleost interrenal tissue in response to a stressor, and thus its circulating levels have been commonly used as a physiological indicator of stress in fish studies (Mommsen et al., 1999; Wendelaar Bonga, 1997).

Crenicichla lepidota Heckel, 1840 (Cichlidae) and Moenkhausia bonita Benine, Castro \& Sabino 2004 (Characidae), are fish species commonly found in the Bonito rivers. The first is a resident, benthonic and invertivore species with a specific reproductive strategy that includes nest building and parental care. The second is a pelagic species that occurs in schools, feeds mostly on terrestrial insects and is an important component of the local food chain. Because they are quite distinctive in their biological traits and $C$. lepidota has been considered by Sabino (2003) as a bioindicator of water quality, they have been chosen as surrogate species for testing the impact of ecotourism beyond ecological parameters.

The objectives of this study were to evaluate the anthropogenic impacts of ecotourism on the fish fauna of Sucuri River in Bonito, Mato Grosso do Sul State, Brazil, using visual censuses to assess changes at the community level and focusing on behavioural and physiological criteria in two surrogate species: Crenicichla lepidota and Moenkhasia bonita.

\section{Material and methods}

\section{Study area}

This study was conducted in Sucuri River, located in the Reserva Particular do Patrimônio Natural (RPPN) São Geraldo, in Bonito, Mato Grosso do Sul State, Brazil (Fig. 1) from December 2005 to March 2007. Ecotourism is locally performed by the practise of snorkelling throughout 1800 $\mathrm{m}$ of the river (Figs. 2-3). Snorkelling is usually performed by groups of about 10 people from $9 \mathrm{~h} 00$ to $16 \mathrm{~h} 00$ everyday, all year around.

Two distinct areas of the river were chosen in order to assess the magnitude of the anthropogenic impacts caused by the daily visit from tourists: (1) No Tourism - where no tourists were allowed and it is legally defined as an area of total protection, hence without direct anthropogenic impact, and (2): Tourism - where the daily visits occur. We established three stationary counting points at each sampling site (i.e., Tourism vs. No Tourism), each point with a $3 \mathrm{~m}$ radius. All points were located in the middle of the river without overlapping.

\section{Ecological characterization}

We have conducted an ecological characterization of both Tourism and No Tourism sites in order to determine whether they were qualitatively and quantitatively comparable (Sabino 


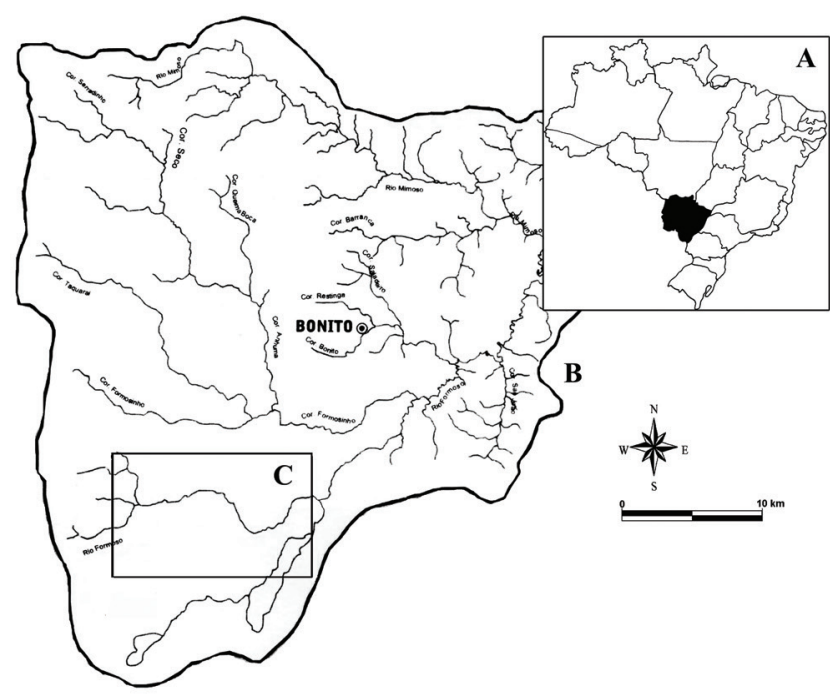

Fig. 1. Map showing the location of the study area: Sucuri River (C), município of Bonito area (B), Brazil (A). Adapted from Miranda \& Coutinho (2004).

$\&$ Andrade, 2002). For this purpose, the following data were collected in each point where fish observations were carried out at both sites: underwater vegetation (by local observation of species presence/absence), bottom type (by observation and local sediment measurements), vertical visibility, horizontal visibility, depth and channel width from shore to shore (using a measurement tape), current speed (by a mechanical flow meter at each 30 seconds with three replicas) and temperature (by an underwater thermometer).

\section{Fish communities}

To assess local variation in fish diversity and abundance, we have performed underwater visual censuses using the "stationary point count" method (Labrosse et al., 2002) in each point defined. A total of 27 samplings of five minutes each were performed in each site during March 2007: at 9h, 13h and $16 \mathrm{~h}$ with three repetitions. We adjusted sampling times after preliminary observations of target species' behaviour. These observations showed no difference in their mobility and as so, all species (benthic and pelagic) were counted during the same five min.

Fish assemblage heterogeneity was specified by calculating species richness (Margalef index), diversity (Shannon-Wiener index), evenness and density (Zar, 1986). We used a repeated measures analysis of variance to assess local (Tourism $v s$. No Tourism sites) and temporal (9h, 13h, and $17 \mathrm{~h}$ ) variations in the above mentioned assemblage parameters, as well as in overall fish density (specimens $/ \mathrm{m}^{2}$ ).

Multivariate analyses were used to assess local and daily time differences in assemblage structure. We transformed the original density matrices of samples by species into a

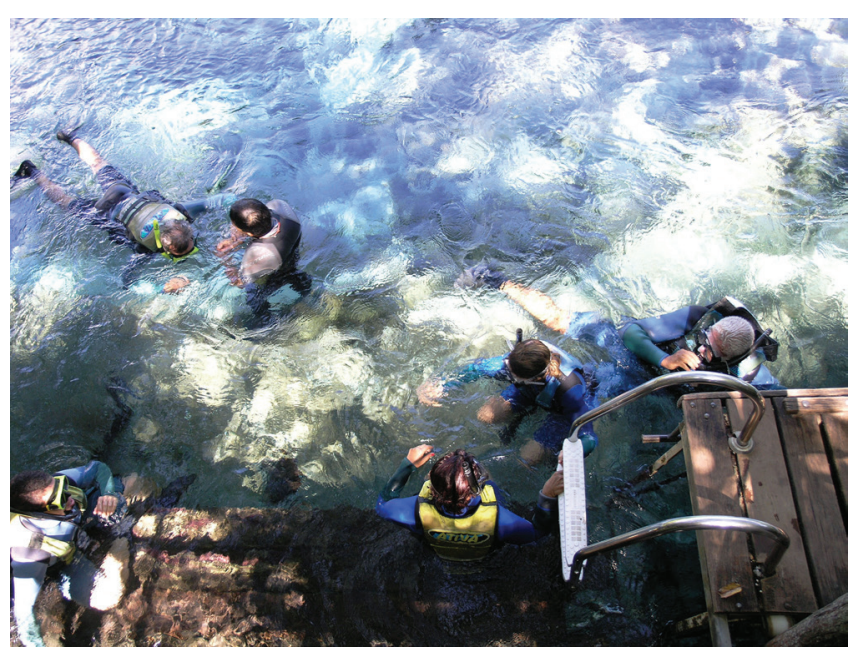

Fig. 2. Image illustrating tourists at the beginning of the snorkeling excursion (Lima, 2008).

Bray-Curtis similarity matrix. Based on the relative abundance of each species, non-metric multidimensional scaling (nMDS) diagrams were used to graphically display the inter-relationships among samples. In each plot, samples that are closer together are more similar to each other. Stress values smaller than 0.15 were considered a good portrayal of data (Clark, 1993). To test for differences between local and daily time, we used a multivariate analysis of similarity (ANOSIM) to identify differences in assemblage groupings (Clark \& Warwick, 2001). Similarity percentages analysis (SIMPER) was used to identify the main taxa responsible for local and daily time groupings, assuming a cut-off at $80 \%$. Differences between sites and the ecological parameters were analysed with Statistica $7.0^{\circledR}$ (Copyright $($ C StatSoft, Inc. 1984-2005) and the multivariate analysis with PRIMER software packages V6.0 $\beta$ R6.

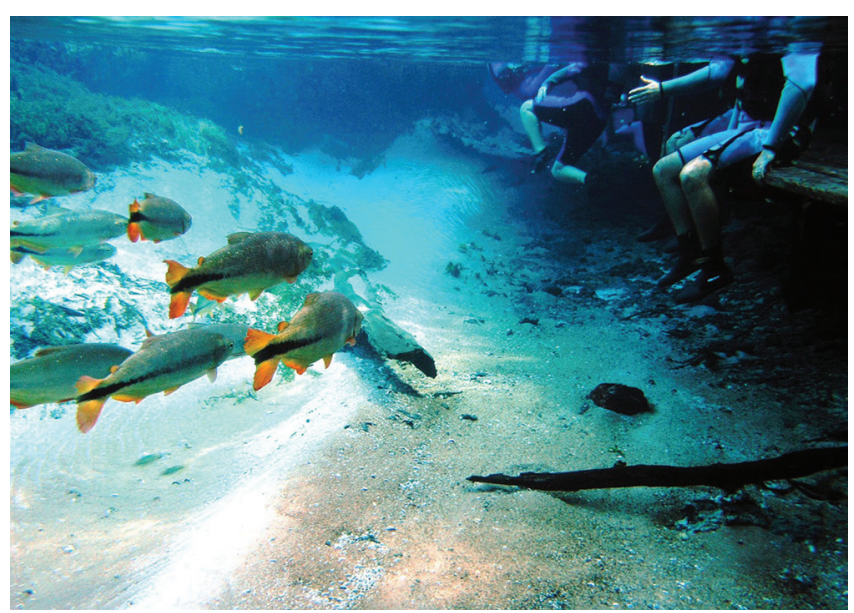

Fig. 3. Image illustrating under water visibility at the beginning of the snorkeling excursion and the presence of tourists (Lima, 2008). 


\section{Behaviour}

Behaviour data were collected for C. lepidota and M. bonita at both sites between the end of October 2005 and February 2006, from $6 \mathrm{~h} 00$ to $19 \mathrm{~h} 00$ by snorkelling observations. " $A d$ libitum" sampling (Martin \& Bateson, 1993) was performed initially, in order to collect data about general aspects of behaviour, spatial distribution and activity period of $C$. lepidota and M. bonita. Focal animal sampling (sensu Martin \& Bateson, 1993) was performed to quantify behaviour patterns previously selected and defined by an ethogram elaborated according to Lehner (1979) and Paixão \& Sabino (1999), specifically for these two species (see Table 1 for a short description of behavior categories). The categories of behavior selected included: Feeding, Agonistic activity, Escape behaviour, Nest protection, and Sexual behaviour for C. lepidota and Feeding, Agonistic activity, and Escape behaviour for M. bonita. We defined the duration of each sampling period according to the behavioural variability of each species. Hence, three min and 1 min Focal animal sampling time were used for C. lepidota and for $M$. bonita respectively. A total of $42 \mathrm{~h}$ of observations were collected for C. lepidota and 28h for M. bonita.

To test for differences between sites concerning the selected patterns of behaviour, globally and in each observation hour (from $6 \mathrm{~h} 00$ to $19 \mathrm{~h} 00$ ), for C. lepidota and M. bonita, MannWhitney $U$-tests (Statistica $7.0^{\circledR}$ ) were used, as parametric assumptions could not be met. We used the same techniques in order to test for differences before the sampling point that corresponds to the first entrance of tourists in the river ( $8 \mathrm{~h} 00$ ), and the next one (9h00) in both study areas. Spearman rank correlations were used to assess the relationship between the total numbers of tourists per day (from $9 \mathrm{~h} 00$ to $16 \mathrm{~h} 00$ ) and the frequency of occurrence of the selected behaviour patterns in the Tourism area.

Table 1. Short description of behaviour categories defined for Crenicichla lepidota and Moenkhausia bonita.

\begin{tabular}{|c|c|c|c|c|c|}
\hline & Feeding & Agonistic activity & Escape behaviour & Nest Protection & Sexual behaviour \\
\hline & $\begin{array}{l}\text { Picking at relatively } \\
\text { small prey }\end{array}$ & $\begin{array}{l}\text { Slow Approximation } \\
\text { to other individual }\end{array}$ & $\begin{array}{l}\text { Speed swim in the } \\
\text { opposite direction of } \\
\text { a treat }\end{array}$ & $\begin{array}{l}\text { Vigilant position from } \\
\text { inside the nest with } \\
\text { head facing out }\end{array}$ & $\begin{array}{l}\text { Female courtship } \\
\text { display showing red } \\
\text { coloration in the } \\
\text { ventral part of the } \\
\text { body }\end{array}$ \\
\hline \multirow[t]{5}{*}{ Crenicichla lepidota } & $\begin{array}{l}\text { Drift feeding close to } \\
\text { the substratum }\end{array}$ & $\begin{array}{l}\text { Speed swim close to } \\
\text { other individual }\end{array}$ & & $\begin{array}{l}\text { Repeated slow swim } \\
\text { near nest's entrance }\end{array}$ & $\begin{array}{l}\text { Spawning in the } \\
\text { substratum inside the } \\
\text { nest }\end{array}$ \\
\hline & Chasing preys & $\begin{array}{l}\text { Unique impulse } \\
\text { effort towards other } \\
\text { individual }\end{array}$ & & & $\begin{array}{l}\text { Mouth incubation of } \\
\text { juveniles in presence } \\
\text { of a treat }\end{array}$ \\
\hline & $\begin{array}{l}\text { Picking up substrate } \\
\text { and sorting prey }\end{array}$ & $\begin{array}{l}\text { Chasing non-welcome } \\
\text { individuals }\end{array}$ & & & $\begin{array}{l}\text { Juveniles protection by } \\
\text { swimming near them }\end{array}$ \\
\hline & $\begin{array}{l}\text { Surface picking } \\
\text { terrestrial insects }\end{array}$ & $\begin{array}{l}\text { Body exhibition } \\
\text { towards other } \\
\text { individual }\end{array}$ & $\begin{array}{l}\text { Speed swim in the } \\
\text { opposite direction of } \\
\text { a treat }\end{array}$ & & \\
\hline & $\begin{array}{l}\text { Drift feeding at the } \\
\text { water column }\end{array}$ & $\begin{array}{l}\text { Caudal Fin exhibition } \\
\text { with head upside-down }\end{array}$ & & & \\
\hline \multirow[t]{4}{*}{ Moenkhausia bonita } & & $\begin{array}{l}\text { Slow Approximation } \\
\text { to other individual }\end{array}$ & & & \\
\hline & & $\begin{array}{l}\text { Speed swim close to } \\
\text { other individual }\end{array}$ & & & \\
\hline & & $\begin{array}{l}\text { Unique impulse } \\
\text { effort towards other } \\
\text { individual }\end{array}$ & & & \\
\hline & & $\begin{array}{l}\text { Chasing non-welcome } \\
\text { individuals }\end{array}$ & & & \\
\hline
\end{tabular}


Table 2. Repeated Measures Analysis of Variance results for Species richness, Shannon-Weiner index, Evenness and Density between daily time (H) (9h, 13h, 16h) and local (L) (No Tourism Vs. Tourism sites). E - error.

\begin{tabular}{|c|c|c|c|c|c|c|c|c|c|c|c|c|}
\hline & \multicolumn{3}{|c|}{ Species Richness } & \multicolumn{3}{|c|}{ Shannon-Wiener index } & \multicolumn{3}{|c|}{ Evenness } & \multicolumn{3}{|c|}{ Density } \\
\hline & Ms & $\mathrm{F}$ & $\mathrm{p}$ & Ms & $\mathrm{F}$ & $\mathrm{p}$ & Ms & $\mathrm{F}$ & $\mathrm{p}$ & Ms & $\mathrm{F}$ & $\mathrm{p}$ \\
\hline $\mathrm{H}$ & 0.15 & 2.99 & 0.06 & 0.014 & 1.68 & 0.20 & 0.001 & 1.38 & 0.27 & 1.31 & 1.84 & 0.175 \\
\hline $\mathrm{L}$ & 1.01 & 42.04 & $<0.001$ & 0.45 & 26.63 & $<0.001$ & 0.007 & 3.60 & 0.08 & 26.68 & 23.47 & $<0.001$ \\
\hline $\mathrm{E}$ & 0.02 & & & 0.02 & & & 0.002 & & & 1.34 & & \\
\hline
\end{tabular}

\section{Physiology}

Cortisol levels for M. bonita were collected from fish holding-water, as the small size of this species is a limitation to the collection of blood samples. This non-invasive method has been successfully used in other species (Bshary et al., 2007; Ellis et al., 2004; Oliveira et al., 1999; Scott et al., 2001) and its validity as a measure of cortisol circulating levels is well established and is based on the following facts: (1) the release of cortisol in the water is closely associated to specific biologically relevant events (e.g., exposure to a stress stimuli); (2) the administration of trophic hormones (ACTH) induces an increase in the concentrations of cortisol in the water; and (3) the pattern of cortisol release in the water reflects the pattern of secretion into the plasma (Scott et al., 2008). In order to measure the cortisol response of $M$. bonita we used a confinement stress protocol consisting of capture, transport and confinement. Ten individuals from each site were captured at the end of the day with a hand-net, weighted, measured for standard length and placed inside individual small aquariums of $500 \mathrm{ml}$ with river water for $1 \mathrm{~h}$. Afterwards the fish were released back into the river and the cortisol levels were assayed from the holdingwater. The water was filtered from each aquarium through a Merck Lichrolut RP - 18 solid phase extraction cartridge, previously activated with $2 \times 5 \mathrm{ml}$ ethanol followed by $2 \times 5 \mathrm{ml}$ distilled water, and adsorbed material was eluted with $2 \times 2 \mathrm{ml}$ ethanol (Scott et al., 2001). The columns were stored at -20 $\mathrm{C}$ until later processing at the lab in Lisbon, Portugal. Free and conjugated steroids (sulphates and glucuronides) were extracted (see Ellis et al., 2004, for the extraction protocol) and the fractions for each sample pooled and radioimmunoassayed for total cortisol. The validation method consisted on using an adrenocorticotropic hormone (ACTH) challenge and check for a cortisol response in holding-water levels. Twelve individuals were captured with a hand-net from both areas of study and placed individual small aquaria of $250 \mathrm{ml}$ with river water. Six individuals were injected with ACTH (Sigma A-6303; 0,023 IU/g body weight) and six control individuals were injected with a saline solution. We performed the water filtering and cortisol extraction the same way as described above and the cortisol response curve in the water was measured. Cortisol levels are used here as an indicator of the stress response for each individual. The rationale for this approach is based on the assumption that individuals that are more responsive to an acute stress situation will increase their allostatic load more rapidly than those that are less responsive. The use of glucocorticoid levels as physiological indices of relative fitness of individuals and/or populations has been increasingly employed in environmental studies (Bonier et al., 2009). Although the relationship between glucocorticoid levels and measures of fitness is not linear, high glucocorticoid levels are usually assumed to indicate poor condition (Bonier et al., 2009).

Non-parametric tests (Mann-Whitney $U$-test, Statistica $7.0^{\circledR}$ ) were used to test the differences between both study sites.

\section{Results}

\section{Ecological characterization}

From the ecological parameters measured, underwater vegetation (dominance of Ceratophylum demersum, Echinodorus ashersonianus, Gonphrena elegans, and Hydrocotyle leucocephala for both sites), bottom type (sandclay $>70 \%$ for both sites), vertical visibility and temperature (No Tourism: $22.03^{\circ} \mathrm{C}, \pm 0.30^{\circ} \mathrm{C}$; Tourism: $22.02^{\circ} \mathrm{C}, \pm 0.32^{\circ} \mathrm{C}$; $\mathrm{F}=1 ; \mathrm{p}=1.0$ ) did not vary significantly between sites, but horizontal visibility (No Tourism: $55.50 \pm 5.10 \mathrm{~m}$; Tourism: $36.75 \pm 4.06 \mathrm{~m} ; \mathrm{F}=1.58 ; \mathrm{p}<0.05$ ) and current speed (No Tourism: $0.26 \pm 0.007 \mathrm{~m} / \mathrm{s}$; Tourism: $0.35 \pm 0.008 \mathrm{~m} / \mathrm{s} ; \mathrm{F}=2.96$; $\mathrm{p}<0.05)$ did.

\section{Fish communities}

Species richness $($ Tourism $=2.0 ;$ No Tourism $=1.7)$, Shannon-Weiner diversity index (Tourism $=1.5$; No Tourism $=1.8$ ) and fish density (Tourism $=11.3 \mathrm{ind} / \mathrm{m}^{2}$; No Tourism $=13.2 \mathrm{ind} / \mathrm{m}^{2}$ ) were significantly higher at the Tourism site (Table 2). When comparing the same parameters and evenness for samples collected at different day times within the same sampling points, there were no significant differences.

The nMDS plot showed a clear separation of samples by local (Fig. 4), which was confirmed by the ANOSIM results (global $\mathrm{R}=0.968, \mathrm{p}<0.001$ ). The SIMPER results showed that for both No Tourism (A) and Tourism (B) sites Phenacogaster tegatus, Astyanax sp. and Moenkausia bonita were the most contributory species to the similarity of groups. 


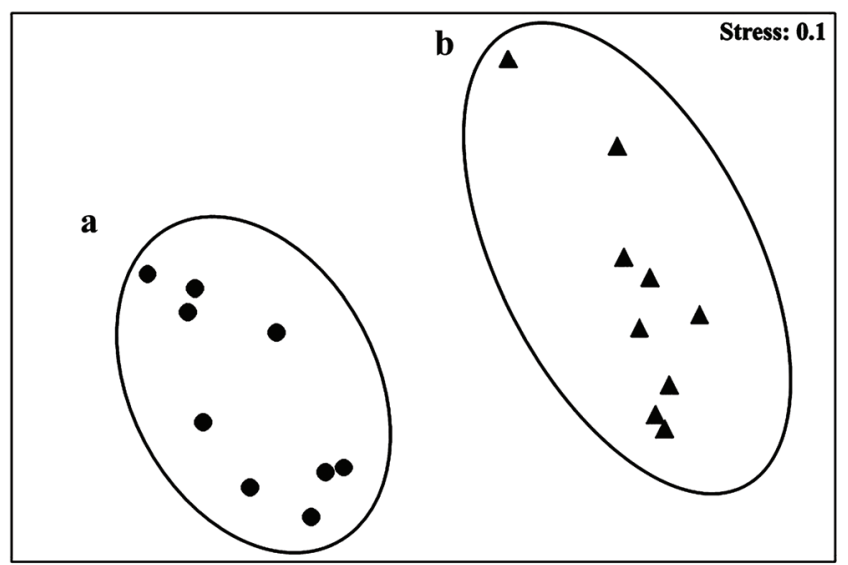

Fig. 4. Multidimensional scaling ordinations showing local differences in (a) No Tourism site and (b) Tourism site. Each individual point represents a replicate sample (census). Circles $=$ No Tourism site Triangles $=$ Tourism site .
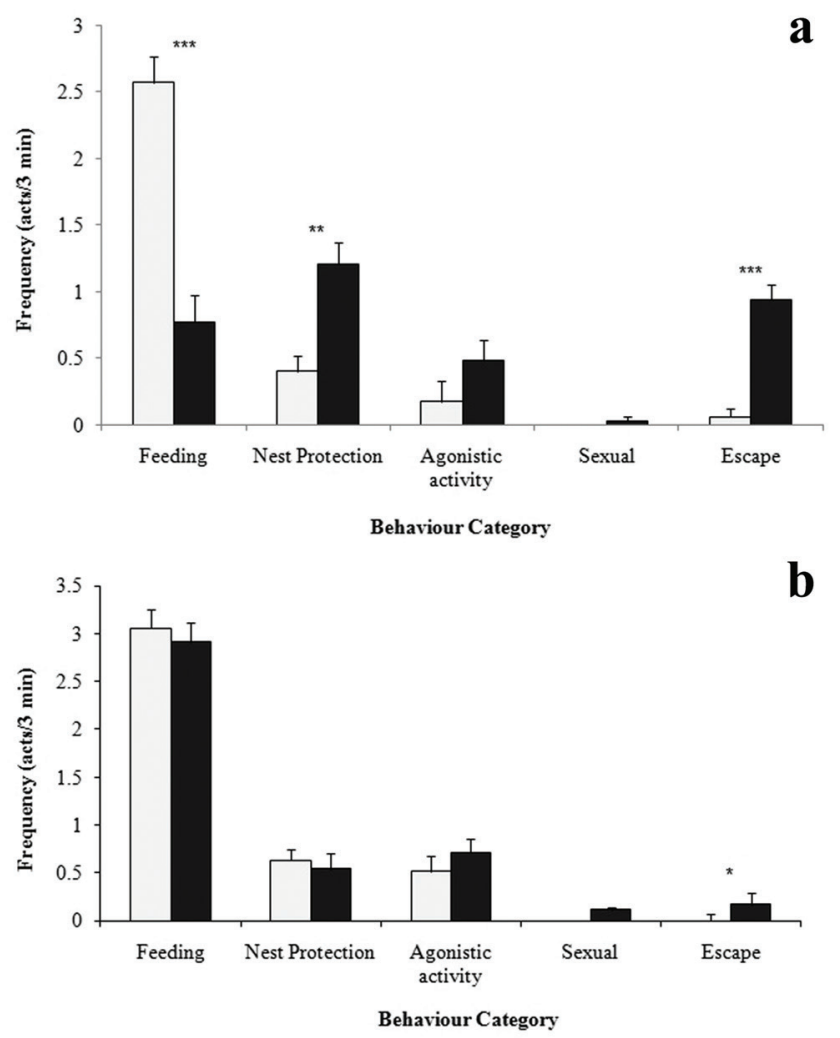

Fig. 5. Variation of behaviour patterns between No Tourism and Tourism sites for Crenicichla lepidota (mean and SEM); (a) Feeding; (b) Agonistic activity; (c) Escape behaviour. Lighter bars $=$ No Tourism site; darker bars $=$ Tourism site. (Mann-Whitney U-test). $\mathrm{N}=35 ; * \mathrm{p}<0.05 ; * * \mathrm{p}<0.01 ; * * * \mathrm{p}<0.0001$.
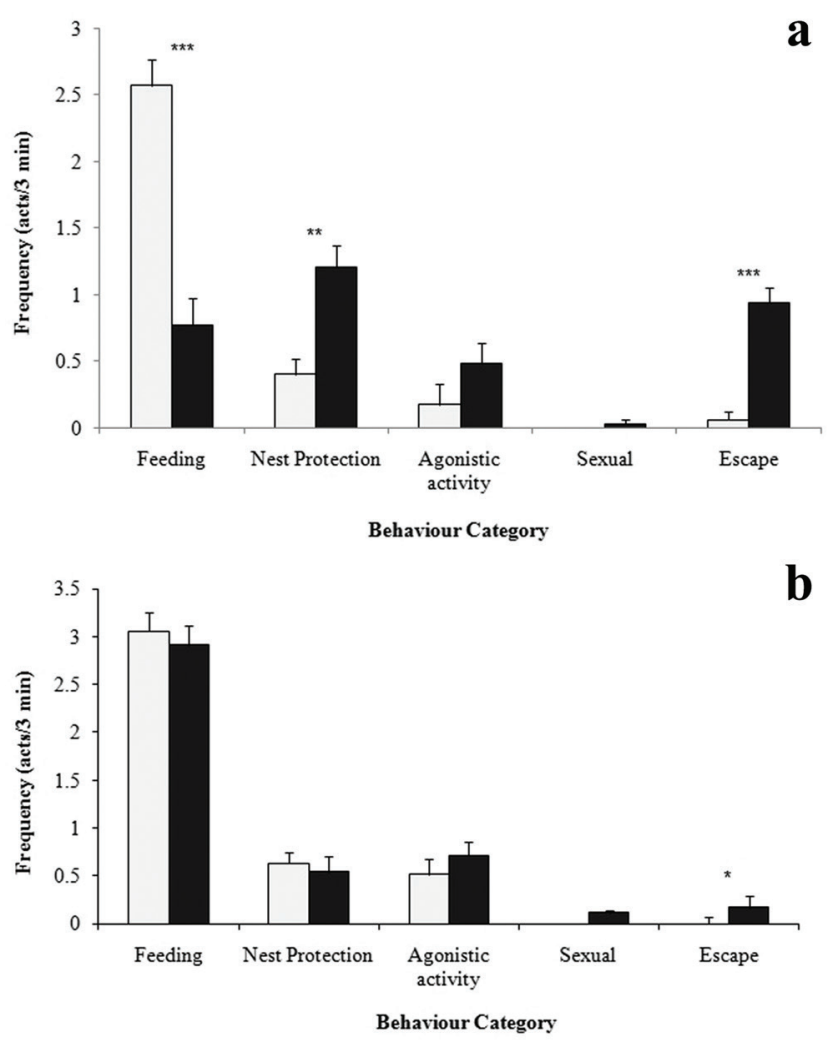

Fig. 6. Variation of behaviour patterns between before $(8 \mathrm{~h} 00)$ and after $(9 \mathrm{~h} 00)$ the first disturbance of tourists in the river (mean and SEM) for Crenicichla lepidota. (a) Tourism; (b) No Tourism. Lighter bars $=8 \mathrm{~h} 00$; darker bars $=9 \mathrm{~h} 00$ (Mann-Whitney U-test). $\mathrm{N}=35 ; * \mathrm{p}<0.05 ; * * \mathrm{p}<0.01 ; * * \mathrm{p}<0.0001$.

\section{Behaviour \\ Crenicichla lepidota}

Overall feeding behaviour $(\mathrm{N}=420 ; \mathrm{Z}=8.81 ; \mathrm{p}<0.0001)$ and agonistic activity $(\mathrm{N}=420 ; \mathrm{Z}=7.16 ; \mathrm{p}<0.0001)$ were significantly higher at the No Tourism site for C. lepidota, whereas the escape behaviour was significantly lower in the same area $(\mathrm{N}=420 ; \mathrm{Z}=-7.30 ; \mathrm{p}<0.0001)$. Nest protection and sexual behaviour showed no significant differences between both study areas.

Crenicichla lepidota feeding behaviour was significantly higher at the No Tourism site than at the Tourism site from $8 \mathrm{~h} 00$ to $18 \mathrm{~h} 00$ (Fig. 5a). In late afternoon (19h00), after tourist have left the river, this pattern was reversed, with fish from the Tourism site showing significantly more feeding behaviour. Agonistic activity was significantly higher at the No Tourism site during the tourist presence in the river (from $9 \mathrm{~h} 00$ to 16h00) (Fig. 5b) and escape behaviour was significantly higher at the Tourism site during the same period of time (Fig. 5c). 

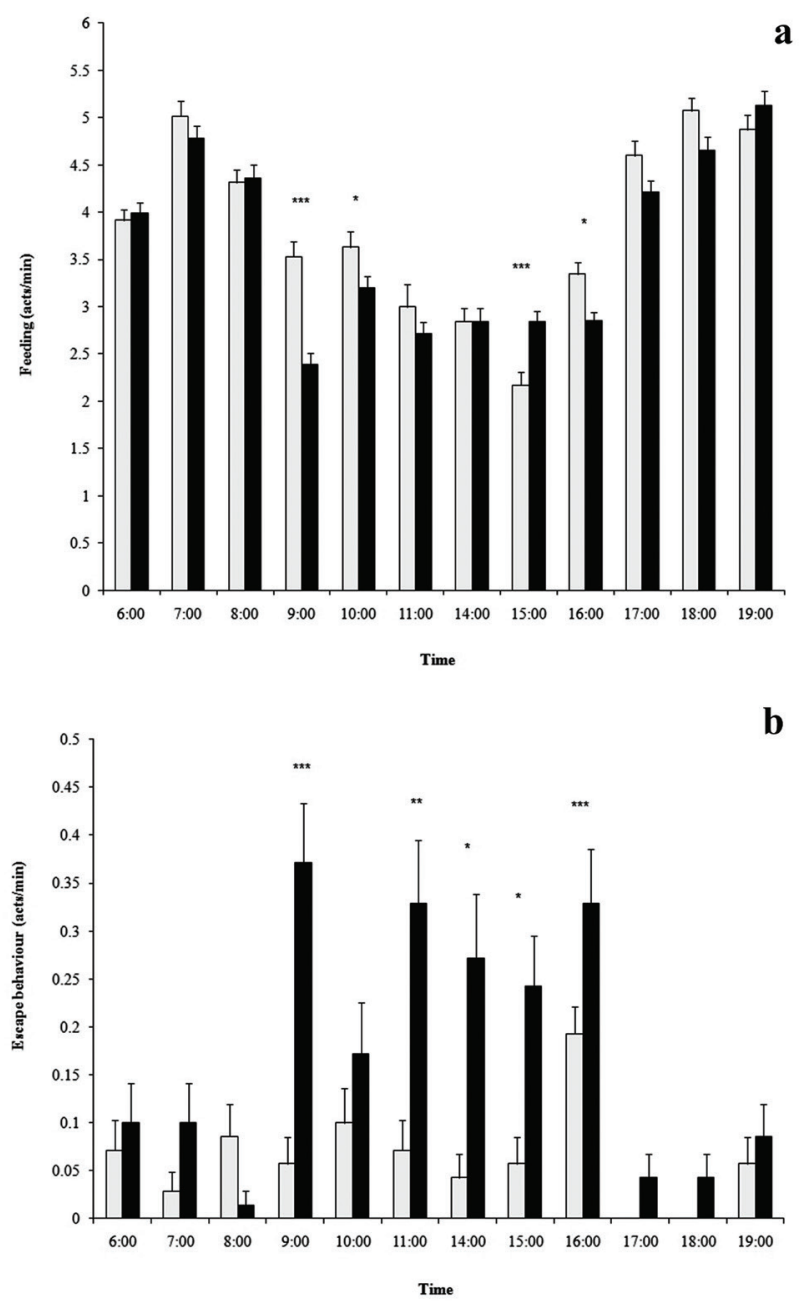

Fig. 7. Variation of behaviour patterns between No Tourism and Tourism site for M. bonita (mean and SEM); (a) Feeding; (b) Escape. Lighter bars $=$ No Tourism; darker bars $=$ Tourism. (Mann -Whitney U-test). $\mathrm{N}=70 ;{ }^{*} \mathrm{p}<0.05 ;{ }^{* *} \mathrm{p}<0.01$; $* * * \mathrm{p}<0.0001$.

In C. lepitoda, Feeding significantly decreased and Nest Protection and Escape behaviour significantly increased at the Tourism site after the first disturbance from tourists in the river (at 9h00) (Fig. 6a). The same behaviour patterns showed no significant difference at the No Tourism site, except for Escape behaviour which was significantly higher at $9 \mathrm{~h} 00$ (Fig. 6b), although no apparent disturbance was observed.

The total number of tourists per day (from $9 \mathrm{~h} 00$ to $16 \mathrm{~h} 00$ ) at the Tourism site showed a negative correlation with feeding behaviour ( $\mathrm{Rs}=-0.93 ; \mathrm{N}=35 ; \mathrm{p}<0.05)$ and a positive correlation with nest protection $(\mathrm{Rs}=0.84 ; \mathrm{N}=35 ; \mathrm{p}<0.05$ ) and escape behaviour ( $\mathrm{Rs}=0.78 ; \mathrm{N}=35 ; \mathrm{p}<0.05$ ). There were no correlations between the total number of tourist per day and Agonistic activity or Sexual behaviour.
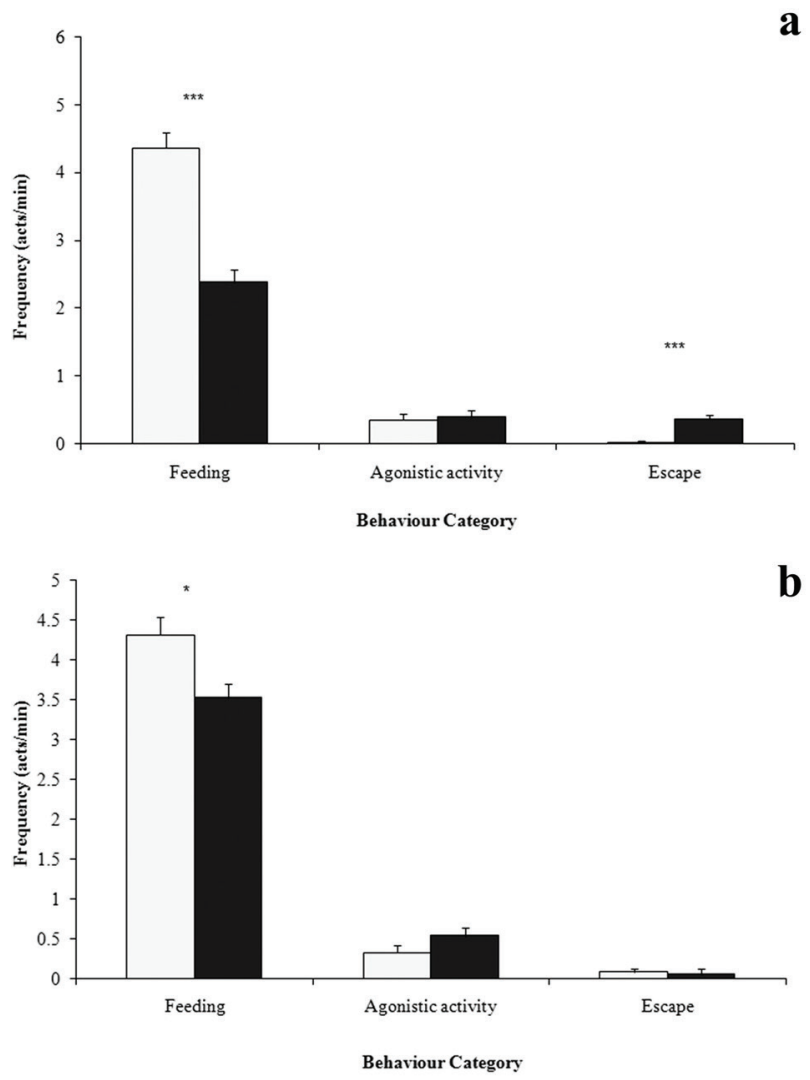

Fig. 8. Variation of behaviour patterns between before ( $8 \mathrm{~h} 00)$ and after (9h00) the first disturbance of tourists in the river (mean and SEM) for M. bonita; (a) Tourism and (b) No Tourism. Lighter bars $=8 \mathrm{~h} 00$; darker bars $=9 \mathrm{~h} 00$ (Mann-Whitney U-test). $\mathrm{N}=70 ; * \mathrm{p}<0.05 ; * * \mathrm{p}<0.01$.

\section{Moenkhausia bonita}

Overall, Feeding $(\mathrm{N}=840 ; \mathrm{Z}=3.02 ; \mathrm{p}<0.05)$ was higher at the No Tourism site for $M$. bonita, whereas escape behaviour $(\mathrm{N}=840 ; \mathrm{Z}=-3.87 ; \mathrm{p}<0.0001)$ was higher at the Tourism site, and agonistic activity showed no significant difference between the two study areas.

During the tourists' presence in the river (from $9 \mathrm{~h} 00$ to $16 \mathrm{~h} 00$ ), feeding was significantly higher at the No Tourism site (Fig. 7a) and escape behaviour was significantly higher at the Tourism site (Fig. 7b).

Feeding significantly decreased after the first disturbance (at 9h00), whereas Escape behaviour significantly increased for individuals from the Tourism site (Fig. 8a). Feeding also significantly decreased at $9 \mathrm{~h} 00$ at the No Tourism site (Fig. 8b), although no significant disturbance was observed.

For $M$. bonita there was also a negative correlation between the total number of tourists per day and feeding behaviour (Rs $=-0.89 ; \mathrm{N}=70 ; \mathrm{p}<0.05$ ), whereas there were no correlations neither with agonistic nor with escape behaviour. 


\section{Physiology}

Despite an initial sampling effort, it was not possible to capture individuals of $C$. lepidota for cortisol measurements due to its behavioural characteristics allied to the fact that the sampling sites are protected areas in natural reserves, and the methodology to capture individuals from this species would involve reasonable disturbances at the substratum. Therefore, we have only collected cortisol data for M. bonita, which has a pelagic behaviour and occupies the water column. Individuals at the Tourism site showed higher holding-water cortisol concentrations than conspecifics from the No Tourism site $(U,: Z=2.95 ; \mathrm{p}<0.005$; Figs. 9 and 10$)$.

\section{Discussion}

Here we present a paradoxical dataset according to which the presence of tourists in the river has an apparent "positive" impact at the level of the fish community (i.e., increased species richness, diversity and density at the Tourism site), but a negative effect at the individual level (i.e., higher stress responses and negative behavioural changes at the Tourism site). In order to solve this paradox one should analyse in more detail the sampled ecological data. Firstly, the comparability of the two areas has to be established. Two ecological parameters tested for both study sites differed significantly: current speed and horizontal visibility. Current speed together with depth were higher at the Tourism site, which allows for the presence of species with larger body sizes, although none of these are direct predators of the two studied species. Hence, this factor appears not to have an immediate influence on the occurrence of other species. Also, although horizontal visibility was higher at the Tourism, this was not considered as a limiting factor for the presence of species in any of the sites once horizontal visibility is very high in the entire river

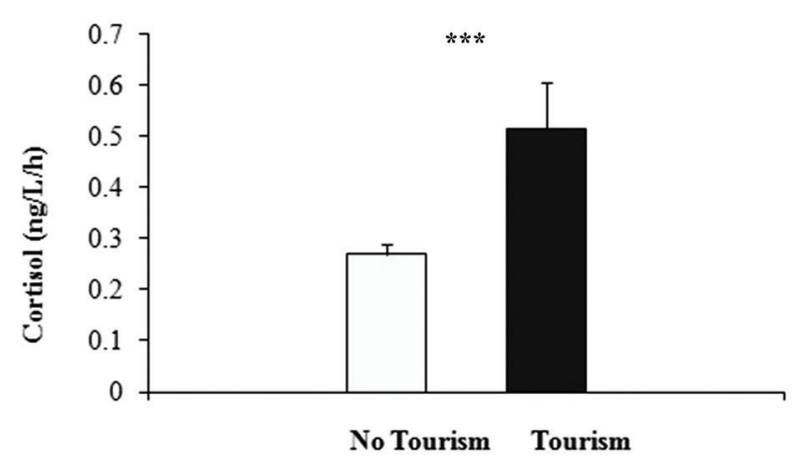

Fig. 9. Variation (mean and SEM) of cortisol responses to restraining stress in Moenkhausia bonita individuals at the No Tourism and Tourism sites (Mann-Whitney U-test, $\mathrm{N}=$ $6 ; \mathrm{Z}=-2.95 ; \mathrm{p}<0.005)$.

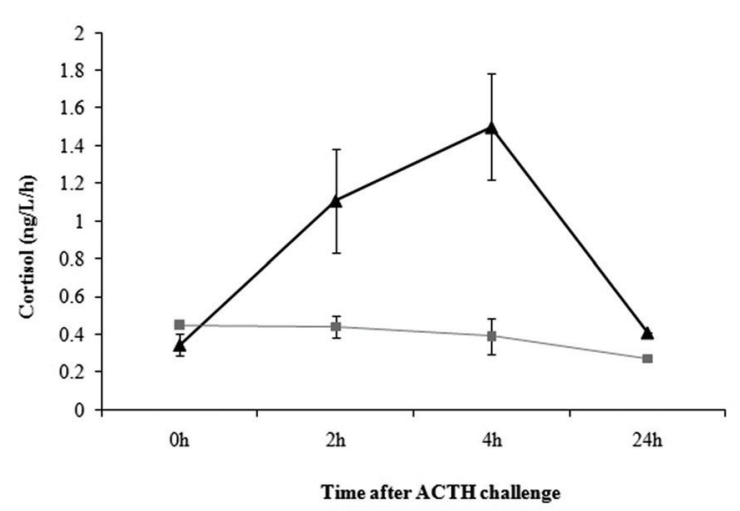

Fig. 10. Temporal variation (mean and SEM) of cortisol levels in holding-water Moenkhausia bonita challenged with an intra-peritoneal injection of porcine ACTH. Triangles, darker line $=$ ACTH; squares, lighter line $=$ RINGER $($ control).

(see Fig. 3). Actually, Sucuri River is considered one of the clearest rivers in the world (Rodrigues, 2003), and most of species occur throughout the $1800 \mathrm{~m}$ of the river (pers. obs.). Hence, although different, horizontal visibility did not limit the visual response distance of species. Once there were no direct limiting factors to the occurrence of the study species in both study sites, they were considered likely to be compared.

The ecological results showed significantly higher values for species richness, diversity and density at the Tourism site. Although there might be the hypothesis that this is due to the difference in the ecological parameters mentioned in the results, it might also suggest that the presence of tourists in the river may have an immediate benefit for some of the bigger species that feed from food items from the shores like seeds and fruits. Food availability may increase as a consequence of visitor's disturbances of the surrounding vegetation making fruits and seeds to fall into the river (pers. obs.). Sabino \& Sazima (1999) support this hypothesis by reporting a feeding association between a Characidae fish that benefits from the activity of foraging primate troops in the riparian vegetation, following the primates and feeding from food items that fall into the water. Also, it is a common practice by local guides to feed the fish with corn before tourists entering the river as a way to attract bigger and visually more appealing species to the site.

The behaviour results showed a feeding suppression in both studied species mainly during the time when tourists were present in the river (from $9 \mathrm{~h} 00$ to 16h00). This was also true at $8 \mathrm{~h} 00$ for $C$. lepidota, suggesting a possible anticipatory learning response, as also suggested for other species (Hollis, 2004; Mathis et al., 1986; Verheijen, 1956; Smith \& Smith, 1989). The significant increase in feeding behaviour at the end of the day observed at the Tourism site may be interpreted as a rebound effect of compensatory feeding. Other studies have demonstrated some species' capacity of compensatory feeding after a stress disturbance (Ali et al., 2001; Rubio et al., 2010; 
Wu et al., 2002), supporting this interpretation. The significantly higher agonistic activity for the same species at the No Tourism site is probably related to the way fish perceive and cope with natural threats $v s$. human threats: at the Tourism site the presence of tourists probably also impacts on predators and other species that interact with our focal species therefore reducing the rate of natural threats to which these animals are exposed to. Hence, the most likely reaction of the individuals was to hide and not to defend themselves. For $M$. bonita the only significant increase in agonistic activity at $19 \mathrm{~h} 00$ at the Tourism site is probably due to an increase in the dispute for food as a way to compensate the suppression verified through the period of touristic activity in the river, as also observed by $C$. lepidota. These results suggest that C. lepidota and M. bonita respond by trying to avoid the visitors, with concomitant changes in their behaviour. This fact can be illustrated by the negative correlation between the total number of tourist per day and feeding behaviour that was observed for both species, as well as the positive correlation between the total number of tourist per day and escape behaviour and nest protection in the case of $C$. lepidota.

Many studies have demonstrated that measurements of cortisol levels can be a useful tool in environmental impact assessments (Washer et al., 2006; Wysocki et al., 2006). The increase of cortisol concentrations at the Tourism site for $M$. bonita suggests that individuals exposed to the presence of tourists throughout the day are more likely to a faster increase in their allostatic load. It is conceivable that individuals who are more easily stressed pay fitness costs in the long run, since stress has detrimental effects on a number of fitness components such as growth, reproduction, immune function and survival (Blas et al., 2007; Korte et al., 2005; Moberg, 2000).

Despite the fact that differences found in the ecological parameters between the two sites might have some influence in our results, this is a novel approach to this question and may indicate that cortisol concentrations in water can be used as an early biological indicator of stress in fresh water fishes exposed to ecotourism. Further studies are, however, necessary to confirm this hypothesis.

While many studies usually implemented to protect natural areas exposed to tourism are only based in general ecological criteria such as species richness, diversity, evenness, and density (e.g., Garay \& Dias, 2001; Mitraud, 2001; Sabino \& Andrade, 2002), our study shows that such approach may not be able to detect the initial signs of disturbance, especially concerning the more sensitive species. The results presented here indicate that stress can first be detected at a more specific level, prior to changes at community level. More research studies with broader scope and using different species are necessary to support this hypothesis. Even so, this is an important preliminary study showing that behavioural and physiological parameters may be used as early indicators of a negative impacts of ecotourism in river ecosystems.

\section{Acknowledgments}

We would like to thank Unidade de Investigação em Eco-Etologia do Instituto Superior de Psicologia Aplicada de Lisboa for financing laboratory reagents and field work equipment, Raoni Rodrigues for helping to collect field data and Tânia Oliveira for helping to validate the holding-water cortisol assay. This study was supported by a grant from Fundação para a Ciência e a Tecnologia (Portugal) (RGLVT-331-2352) to RFO.

\section{Literature Cited}

Ali, M., Y. Cui, X. Zhu \& R. J. Wootton. 2001. Dynamics of appetite in three fish species (Gasterosteus aculeatus, Phoxinus phoxinus, and Carassius auratus gibelio) after feed deprivation. Aquaculture Research, 32: 443-450.

Blas, J., R. Bortolotti, J. L. Tella, R. T. Baos \& A. Marchant. 2007. Stress response during development predicts fitness in a wild, long lived vertebrate. Proceedings of the National Academy of Sciences of the United States of America, 104: 8880-8884.

Bonier, F., P. R. Martin, I. T. Moore \& J. C. Wingfield. 2009. Do baseline glucocorticoids predict fitness? Trends in Ecology \& Evolution, 24: 634-42.

Bshary, R., R. F. Oliveira, T. Oliveira \& A. V. M. Canário. 2007. Cleaning organisms reduce the stress response of client reef fish. Frontiers in Zoology, 4: 21.

Buck, S. M. \& I. Sazima. 1995. An assemblage of mailed catfishes (Loricariidae) in southeastern Brazil: distribution, activity, and feeding Ichthyological Exploration of Freshwaters, 6: 325-332.

Buckley, R. 1999. Tools and Indicators for Managing Tourism in Parks. Annals of Tourism Research, 26: 207-210.

Buckley, R. C. 2001. Ecotourism accreditation in Australia. In: Font, X. \& R. C. Buckley (Eds.). Tourism Ecolabelling: certification and promotion of sustainable management. Pp. 165-174. Wallingford, UK: CABI.

Cifuentes, M. 1992. Determinación de capacidad de carga turística en áreas protegidas. Turrialba: Centro Agronómico Tropical de Investigación y Enseñanza - CATIE. España.

Clark, K. R. 1993. Non-parametric multivariate analyses of changes in community structure. Australian Journal of Ecology, 8: 117-143.

Clarke, K. R. \& R. M. Warwick. 2001. Change in marine communities - an approach to statistical analysis and interpretation. $2^{\text {nd }}$ edition, PRIMER-E, Plymouth.

Cole, D. N. 1993. Minimizing conflict between recreation and nature conservation. Pp. 105-102. In: Smith, D.S. \& P. C. Hellmund (Eds.). Ecology of greenways: Design and function of linear conservation areas. University of Minnesota Press, Minneapolis.

Colton, D. E. \& W. S. Alevizon. 1981. Diurnal variability in a fish assemblage of a Bahamian coral reef. Environmental Biology Fishes, 6: 341-345.

Duffus, D. A. \& P. Dearden. 1990. Non-consumptive wildlifeoriented recreation: a conceptual framework. Biological Conservation, 53: 213-232.

Ellis, T., J. D. James, C. Stewart \& A. P. Scott. 2004. A non-invasive stress assay based upon measurement of free cortisol released into the water by rainbow trout. Journal of Fish Biology, 65: 1233-1252.

Fennell, D.A.1999. Ecotourism: An Introduction. Routledge, New York. FSBI. 2002. Fish Welfare. Briefing Paper 2, Fisheries Society of the British Isles, Granta Information Systems. 
Garay, I. \& B. F. S. Dias. 2001. Conservação da Biodiversidade em Ecossistemas Tropicais: avanços conceituais e revisão de novas metodologias de avaliação e monitoramento. Editora Vozes, Petrópolis.

Hart, P. J. B. 1997. Foraging Tactics. Pp. 104-133 In: Godin, J. G. J. (Ed.). Behavioural Ecology of Teleost Fishes: Chapter 5. Oxford University Press, Oxford.

Hollis, K. L. 2004. The Role of Learning in the Aggressive and Reproductive Behavior of Blue Gouramis, Trichogaster trichopterus. Environmental Biology of Fishes, 54: 355-369.

Karr, J. R. \& D. R. Dudley. 1981. Ecological perspective on water quality goals. Environmental Management, 5: 55-68.

King, D. A. \& W. P. Stewart. 1996. Ecotourism and comodification: protecting people and places. Biodiversity and Conservation, 5: 293-305.

Korte, S. M., J. M. Koolhaas, J. C. Wingfield \& B. S. McEwen. 2005. The Darwinian concept of stress: benefits of allostasis and costs of allostatic load and the trade-offs in health and disease. Neuroscience \& Biobehavioral Reviews, 29: 3-38.

Labrosse, P., M. Kulbicki \& J. Ferraris. 2002. Underwater Visual Fish Census: Proper use and implementation. Pp. 25-39. Reef Resources Assessment Tools. Copyright, Secretariat of the Pacific Community, New Caledonia.

Liddle, M. J. 1997. Recreational ecology: the ecological impact of outdoor recreation and ecotourism. London. Chapman and Hall, Melbourne.

Lima, S. L. 1998. Predator induced stress and behaviour. Advances in the Study of Behavior, 27: 215-290.

Martin, P. \& P. Bateson. 1993. Measuring Behaviour - An introductory guide. Cambridge University Press, London.

Mathis, A., D. P. Chivers \& R. J. F. Smith. 1996. Cultural transmission of predator recognition in fishes: intraspecific and interspecific learning. Animal Behaviour, 51: 185-201.

McEwen, B. S. 1998. Stress, adaptation, and disease: allostasis and allostatic load. Pp. 33-55. In: McCann, S. M., J. M. Liptin, E. M. Sternberg, G. P. Chrousos, P. W. Gold \& C. C. Smith. Neuroimmunomodulation: molecular aspects, integrative systems, and clinical advances. Annals of the New York Academy of Sciences, New York.

McEwen, B. S. \& J. C. Wingfield. 2003. The concept of allostasis in biology and biomedicine. Hormones and Behavior, 43: 2-15.

Miranda, E. E. de \& A. C. Coutinho (Coord.). 2004. Brasil Visto do Espaço. Campinas: Embrapa Monitoramento por Satélite. Available from: http://www.cdbrasil.cnpm.embrapa.br.

Mitraud, S. F. 2001. Uso Recreativo do Parque Nacional Marinho de Fernando de Noronha: um exemplo de planejamento e implementação. WWF Brasil, Brasília.

Moberg, G. P. 2000. Biological response to stress: implications for animal welfare. Pp. 123-146. In: Moberg, G. P. \& J. A. Mench (Eds.). The Biology of Animal Stress. CABI Publishing, California.

Mommsen, T. P., M. M. Vijayan \& T. W. Moon. 1999. Cortisol in teleosts: dynamics, mechanisms of action, and metabolic regulation. Reviews in Fish Biology and Fisheries, 9: 211-268.

Mullner, A., K. E. Linsenmair \& M. Wikelski. 2004. Exposure to ecotourism reduces survival and affects stress response in hoatzin chicks (Opisthocomus hoazin). Biological Conservation, 118: 549-558.

Newsome, D. S., A. Moore \& R. K. Dowling. 2002. Natural Area Tourism: Ecology, Impacts and Management. Channel View Publications, Sydney.

O'Connor, K. I., A. C. Taylor \& N. B. Metcalfe. 2000. The stability of standard metabolic rate during a period of food deprivation in juvenile Atlantic salmon. Journal of Fish Biology, 57: 41-51.
Oliveira, R. F., A. V. M. Canário \& R. Bshary 1999. Hormones, behaviour and conservation of littoral fishes: current status and prospects for future research. Pp. 149-178. In: Almada, V. C., R. F. Oliveira \& E. J. Gonçalves (Eds.). Behaviour and Conservation of Littoral Fishes. Instituto Superior de Psicologia Aplicada, Lisbon.

Pitcher, T. J. \& J. K. Parrish. 1993. Functions of shoaling behaviour in teleosts. Pp. 363-439. In: Pitcher, T. J. (Ed.). Behaviour of Teleost. Chapman and Hall, London.

Rodrigues, A. B. 2003. Ecoturismo no Brasil: possibilidades e limites. Editora Contexto, São Paulo.

Rome, A. 1999. Ecotourism impact Monitoring: A Review of Methodologies and Recommendations for Developing Monitoring Programs in Latin America. Ecotourism Program Technical Report Series No. 1. The Nature Conservancy, Washington.

Rubio, V. C., E. Sanchez \& J. M. Cerdá-Reverter. 2010. Compensatory feeding in the sea bass after fasting and physical stress. Aquaculture, 298: 332-337.

Sabino, J. \& L. P. Andrade. 2002. Monitoramento e conservação no rio Baía Bonita, região de Bonito, Mato Grosso do Sul, Brasil. Pp. 397-404. In: Anais do III Congresso Brasileiro de Unidades de Conservação. Rede Pró-Unidades de Conservação. Rede Próunidades de Conservação, Fundação Boticário de Proteção da Natureza e Associação Caatinga. Fortaleza, Ceará.

Sabino, J. \& L. P. Andrade. 2003. Uso e Conservação da Ictiofauna no Ecoturismo da Região de Bonito, Mato Grosso do Sul: O Mito da Sustentabilidade Ecológica no Rio Baía Bonita (Aquário Natural de Bonito). Biota Neotropica, 3: 1-9.

Sabino, J. \& Sazima, I. 1999. Association between fruit-eating fish and foraging monkeys in western Brazil. Ichthyolgical Exploration of Freshwaters, 10: 309-312.

Sabino, J. \& J. A. Zuanon, 1998. A stream fish assemblage in Central Amazonia: distribution, activity patterns and feeding behavior. Ichthyological Exploration of Freshwaters, 8: 201-210.

Sazima, I. 1986. Similarities in feeding behaviour between some marine and freshwater fishes in two tropical communities. Journal of Fish Biology, 29: 53-65.

Scott, A. P., K. Hirschenhauser, N. Bender, R. F. Oliveira, R. L. Earley, M. Sebire, T. Ellis, M. Pavlidis, P. Hubbard, M. Huertas \& A. V. M. Canario. 2008. Non-invasive measurement of steroids in fish-holding water: important considerations when applying the procedure to behaviour studies. Behaviour, 145: 1307-1328.

Scott, A. P., M. Pinillos \& T. Ellis. 2001. Why measure fish steroids in plasma when you can measure them in water. Pp. 1291-1295. In: Goos, H. J. T., R. K. Rastogi, H. Vaudry, R. Pierantoni. (Eds.). Perspectives in Comparative Endocrinology: Unity and Diversity. Monduzzi Editore, Bologna.

Shumway, C. A. 1999. A neglected science: applying behaviour to aquatic conservation. Environmental Biology of Fishes, 55: 183-201.

Smith, R. J. F. \& M. J. Smith. 1989. Predator-recognition behaviour in two species of gobiid fishes, Asterropteryx semipunctatus and Gnatholepsis anjerensis. Ethology, 83: 19-30.

Smyth, R. L., M. C. Watzin \& R. E. Manning. 2005. Defining Acceptable Levels for Ecological Indicators: An Approach for Considering Social Values. Environmental Management, 39: 301-315.

Takahashi, L. Y. 1997. Limite aceitável de câmbio (LAC): Manejando e monitorando visitantes. Pp. 445-464. In: Takahashi, L. Y. Anais do I Congresso Brasileiro de Unidades de Conservação: vol. I. IAP/UNILIVRE, Curitiba.

Thompson, M. J. \& T. W. Schmidt. 1977. Validation of the species/ time random count technique sampling fish assemblages. Third Internal Coral Reef Symposium, 1: 283-288. 
Verheijen, F. J. 1956. Transmission of a fright reaction amongst a school of fish and the underlying sensory mechanisms. Experientia, 12: 202-204.

Wendelaar Bonga, S. E. 1997. The stress response in fish. Physiological Reviews, 77: 591- 625.

Willink, P. W., B. Chernoff, L. E. Alonso, J. R. Montanbault \& R. Lourival. 2000. A Biological Assessment of the Aquatic Ecossistems of the Pantanal, Mato Grosso do Sul, Brazilian Bulletin of Biological Assessment, 18: 122-127.

Wu, L., S. Xie, Y. Cui \& R. J. Wootton. 2002. Feeding dynamics in fish experiencing cycles of feed deprivation: a comparison of four species. Aquaculture Research, 33: 481-489.
Wysocki, L. E., J. P. Dittamiand \& F. Ladich. 2006. Ship noise and cortisol secretion in European freshwater fishes. Biological Conservation, 128: 501-508.

Zar, J. H. 1986. Biostatistical analysis, $3^{\text {rd }}$ edition. Prentice Hall, New Jersey.

Submitted April 20, 2013

Accepted October 21, 2013 by Jansen Zuanon

Published March 31, 2014 